\title{
RELATIONSHIP BETWEEN EQUITY INCENTIVE AND CORPORATE PERFORMANCE IN LISTED COMPANIES FROM THE EMPIRICAL POINT OF VIEW
}

\author{
Yinghui Bai \\ Nantong University, P.R.China \\ Guohua Wang* \\ Nantong University, P.R.China
}

\begin{abstract}
Equity incentive is an effective long-term incentive system to solve the principal-agent problems appeared in the middle of the twentieth Century, making manager-sable to participate in corporate decision-making with the identity of shareholders, share the profits and risks. Equity incentive promote the effective growth of enterprise performance. With the revolution of equity division of china, many listed companies were putting equity incentive on the agenda, and the internal governance situation and external market environment of public companies were greatly improved, which objectively promoted the fast development of stock ownership incentive mechanism. But the implementation of the equity incentive plan is different, the implementation effect of each are not identical. This paper studies to improve the understanding of equity incentive, improve the listing Corporation's equity incentive program, which helps to improve the efficiency of management of listing Corporation. This study attempts to implement equity incentive to domestic company as the research object, using the Shanghai and Shenzhen City listing Corporation data, by using the method of comparative analysis, case analysis, regression analysis, analysis of the relationship between equity incentive and corporate performance from the empirical point of view.
\end{abstract}

Keywords: Equity Incentive; Enterprise Performance; Incentive Effect; Empirical Analysis

JEL code: M0, M1 


\section{Summary of equity incentive and corporate performance}

\subsection{Modes of equity incentive}

Nowadays general modes of equity incentive are: spot share, share option, stock appreciation rights (SARs), phantom stocks,restricted shares, employee stock ownership plan (ESOP), performance share etc. Here introduces some modes that are mostly popular among enterprises.

\section{1) Share Option}

Share option is a right the company gives the incentive object that he can purchase a certain number of the company's floating shares with a predestined price in a certain time. Or he can give up the right to purchase the shares, but the share option itself is non-transferable.

Advantages of share option are: (1) It is a right rather than an obligation, the holders can give it up when share price is lower than the exercise price. (2) As equity incentive needs certain time or conditions to realize, the incentive object will try to enhance the company's performance to reach the conditions or to increase the share price to earn the profit of price difference, thus making share option have the effects of long-term incentive. (3) Its cost is based on the appreciation of the enterprise's shares, so it is beneficial to reduce the enterprise's cash pressure.

Disadvantages of share option are: (1) Risk from the stock market. The operational process of share option will be affected by the risk of capital market, making the share price not the true reflection of the real situation of the entity, increasing the holding risk of share option holders in a certain level. (2) Risk from the managers themselves. As share option is a right rather than an obligation, shareholders won't have to take responsibility while exercising the right, in the implementation process there will be asymmetry before and after the payment of remuneration. Also, shareholders will gain enormous benefit after the success of rick projects but will not be punished if the projects fail, which easily causes the increase of short-term behavior of managers, deteriorating the future development of the enterprise.

\section{2) Phantom Stocks}

Phantom stock is a kind of fictitious stock that the company gives the incentive object, which will make the grantees enjoy the dividend rights and the benefit of appreciation of share price if the performance target of the company is realized. However, this kind of shareholders do not have any ownership or voting rights, nor can the shares be transferred or sold, the shares will be invalid automatically once the grantees leave the company. Phantom stock shares the residual claim of the company with shareholders, making their long-term profit relate to the corporate performance. 
Advantages of phantom stock: (1) It is a document of the holders' rights to enjoy the dividend of the enterprise, while it doesn't make shareholders have the rights which attach to real shares, which makes no effect on the capital structure and the shareholder structure of the company. (2) It has dual effects of both motivation and constraints. It binds the benefit of the holders with the benefit of the enterprise. When managers operate the enterprise well and make good performance, the holders may gain profit, which causes risk and uncertainty of the gain of holders as it comes from the future performance of the enterprise, making the phantom stock mode constraint the operators in a certain level.

Disadvantages of phantom stock: (1) It easily causes the operators to pay excessive attention to short-term benefit, by investing some high-risk projects. (2) In this mode, the entity has strong will for dividends, which causes high liquidity pressure for the operation of the company. So it is appropriate for listed companies which are steady and have abundant cash flow or unlisted companies which has abundant cash flow.

\section{3) Restricted Shares}

Restricted shares are a certain number of shares the company gives the incentive objective in a predestined condition, which the grantee can't dispose in his will in the restriction limit, but can only be sold when specific performance targets are met or the stipulated service limit is due, otherwise the company has the right to take back the granted restricted shares.

Advantages of restricted shares: (1) The incentive objects do not have to pay any cash. (2) The incentive objects can focus on the long-term strategic objectives of the company.

Disadvantages of restricted shares: (1) It is difficult to ascertain the performance targets and the share price. (2) The cash flow pressure is high. (3) The incentive objects actually own the shares, which makes the company hard to control them. (4) The incentive objects have shareholders' rights. So restricted shares is appropriate for listed companies which have bad performance or in adjusting process of industry, or enterprises in start-up stage.

\section{4) Performance Share}

Performance share mode means that the company will set an an appropriate annual performance target in the beginning of the year, if the incentive objects reach the target in a set limit, the company will grant them a certain number of shares or a certain number of money award to purchase the shares.

The main advantages of performance share are that it will motivate the operators to reach the target by hard work, thus enhancing the corporate performance, and the incentive objects will also become the shareholders. Thereby the benefits of the owners and the operators are bound together. 
The main disadvantages of performance share are that it is hard to assure the effectiveness of the company's performance target, which easily cause the incentive objects to defraud in order to gain the performance shares. So performance share mode is fit for listed companies which have steady performance and their group companies and subsidiaries.

\subsection{Effects of equity incentive}

As a new mode of distribution, equity incentive can change the remuneration structure of the corporate managers, it has enough motivation power and it lasts a long time, which is beneficial to smoothening interest distribution relationship in the agency problem, and to prevent short-term operating behavior of managers. In the process of implementing equity incentive, the enterprise can enhance the corporate performance and obtain the objectives of motivation and constraint by taking concrete actions to recognize the managers and employees, which displays the effects of equity incentive. When the enterprise comes into a bottleneck, implementing equity incentive can adjust the internal capital structure of the enterprise, release the potential of the organization, detain talents, reform empirical management, increase the competitiveness of the company, promote the share price, motivate the operators and promote the long-term sustainable development of the entity.

Firstly, equity incentive has incentive effects. Equity incentive can improve the initiative of the incentive objects, stimulate their sense of responsibility and mission, make them work hard for the future development of the enterprise, raise the productivity and capital operation efficiency of the enterprise, strengthen the corporate cohesion by giving some kind of shares to senior managers and employees, thus maximizing the corporate value. Granting shares is a long-term action which is more beneficial to the future development of the enterprise.

Secondly, equity incentive has the constraint effects. When managers have shares, it means that their own benefits are bound together with the enterprise's benefits, the opportunity cost of weakening internal control, cutting down agent cost and the demission of senior managers is getting higher, which makes operators control their own behaviors spontaneously (e.g. investing more wisely, decreasing short-term behaviors), thus obtaining the objective of constraining the operators' own behavior and benefiting the long-term development of the entity.

Finally equity incentive has the corporate revenue effect. Within so many modes of equity incentive, most of them are not directly involved in the inflow or outflow of cash, enjoying tax benefits at the same time, but some modes are involved in the change of the corporate capital structure. The purpose of measures of motivation or restriction an enterprise takes is to realize the maximization of the corporate value or the maximization of the shareholders' value, so the corporate revenue effect becomes the fundamental effect of equity incentive.

Of course, no one mechanism can become perfect, equity incentive also has disadvantages:

First, equity incentive may have some vulnerabilities which can be taken advantage of by 
operators in the actual operating process. The operators may take bad means to raise the share price in a short term to realize their own benefits quickly, which also causes the fake prosperity of the enterprise and makes investors not able to allocate capital rationally, damaging the corporate benefits as well as the rational allocation of the whole capital market. Second, equity incentive easily leads to high earnings of managers. In the actual operating process, some companies give operators excessive share option in proportion of the whole remuneration, which directly damages the benefit of other shareholders when managers sell these shares for enormous profit by insider dealing or using the supervision loopholes in the capital market.

Finally, when the corporate performance comes into a bottleneck or declines, equity incentive becomes a burden. When some companies face bad performance, they issue rights shares to senior managers or set another price for the option to retain talents, which makes senior managers own benefits like lower exercise price, but increases the operating cost as well as burden of the company at the same time.

\subsection{Proposal of the research hypothesis}

It can be concluded from the concept of equity incentive and the analysis of the theoretical basis that equity incentive is a salary incentive mechanism which resolves the agency problem between shareholders and operators. The implementation of equity incentive makes operators and employees work hard and put more effort on the long-term development of the company, which improves the corporate performance.

Hypothesis 1: The implementation of equity incentive can improve the corporate performance as a whole.

It can be concluded from the effect analysis of equity incentive that the implementation of equity incentive brings the operators' and shareholders' benefits to a convergence. The higher the level of equity incentive, the greater the incentive effect to operators and employees and the harder they work, thus improving the corporate performance.

Hypothesis 2: The proportion of equity incentive has positive correlation with corporate performance.

From the current situation in China that most listed companies choose only share option and restricted shares, as well as the prior introduction of the definition and advantages and disadvantages of these two modes of equity incentive, it can be concluded that share option only has the exercise right while the holders don't have an obligation to exercise the right. It only has incentive effects but not punishment effects. Restricted shares, however, has symmetrical rights and obligations, so it has both incentive and restriction effects.

Hypothesis 3: The implementing effect of restricted shares is better than that of share option. 


\section{Analysis of the impact of equity incentive to the corporate performance}

\subsection{The transmission mechanism of equity incentive to the corporate performance}

Equity incentive relates the share price to the performance of operators, pushing them to work harder. The key factor of share price increase is the information operators provide and the reflection investors give. While in the capital market, information asymmetry exists between investors and operators. Investors observe the performance of listed companies through the fluctuation of the share price, while operators get to know the market estimate for the future development of the company form the fluctuation of share price. So, the information of share price has two functions: First, share price reflects the demand of market investors; second, share price can direct the capital flow of the capital market and assess the performance of the enterprise. The information contained in the share price comes from the production of operators and investors, in which operators provide information of the company's projects in order to attract investors to invest while investors provide the anticipation the market has on the enterprise that directs operators allocate the resources appropriately. Investors and operators make money form the creation of share price to the production of the information of the share price, which makes the information contained in the share price have dual functions. After operators obtain information from the share price, they can either obey the guidance of the share price signals and choose good invest decisions to make money or they can choose the most beneficial invest scheme due to the information they obtain. If decisions are made in the perspective of the operators, only profits of operators themselves instead of profits of the company and shareholders can be improved, which leads to the increase of agent cost. So it is necessary to take incentive measures on operators to improve the corporate performance.

Implementing equity incentive can achieve two objectives: First, It can motivate operators to produce information positively, which makes the performance shown in the share price, increases the operating efficiency of the capital market and allocates the capital appropriately. Second, after operators gain equity incentive, they have the residual claim of the company, which makes them make decisions from the perspective of the company and the shareholders due to theshare price signals and allocate the company's economic resources appropriately. After the appropriate and effective allocation of the company's resources, the performance and share price of the company will be improved, which as in turn will improve the share price held by operators and increases their profits. It can be concluded that equity incentive relates the information of share price to the behavior and personal profits of operators, delivers operating and investing information through the fluctuation of the share price and chooses to give operators corresponding rewards or punishments due to their decisions.

All in all, equity incentive's transmission mechanism of corporate performance can be concluded this way: Motivating investors from stock market and corporate operators to produce information of allocation of resources positively, delivering the information through the share price signals, realizing the efficient allocation of capital in the capital market and the 
appropriate arrangements of the corporate resources, improving the corporate operating performance. In addition, equity incentive reflects the hardness of the operators' work and their operating results on the share price, which benefits shareholders' judgement on the work of operators, improves the information asymmetry between them, reduces agent cost and improves operating performance.

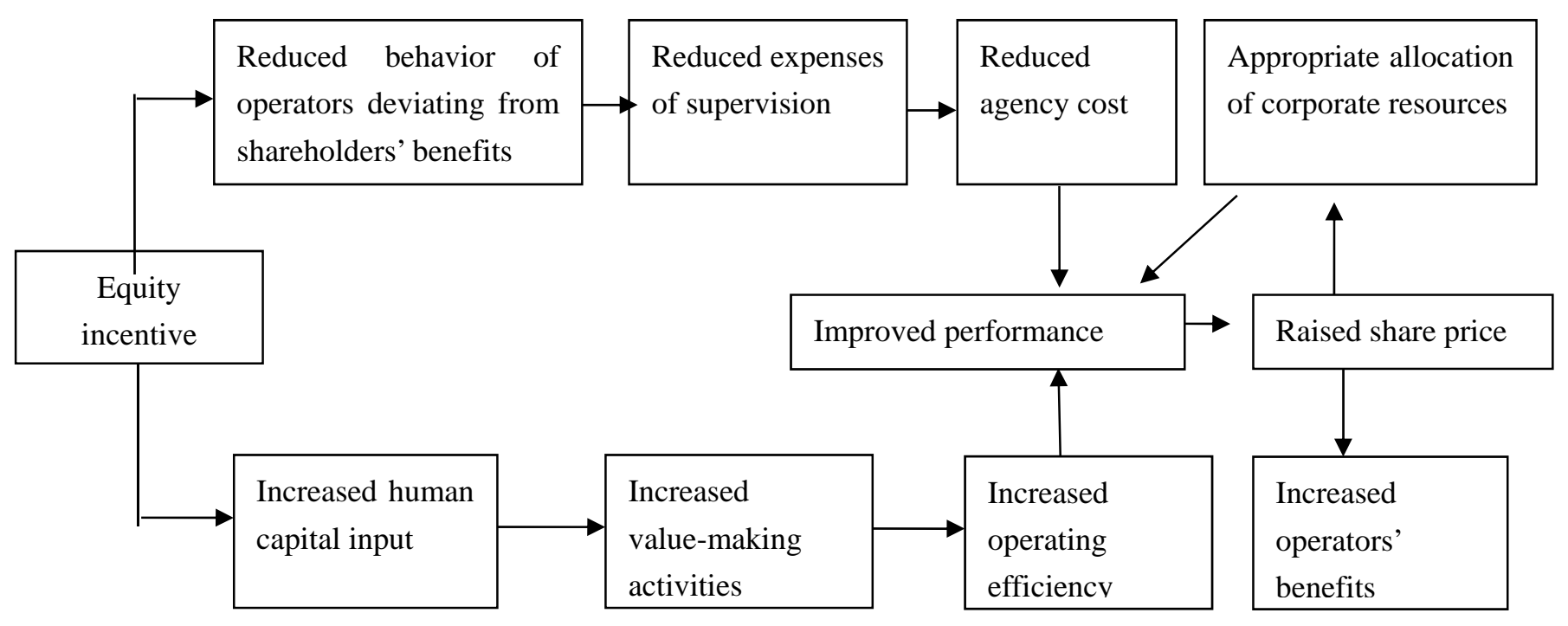

Figure 1: The operating process of equity mechanism

\subsection{Case study-----Wanke}

Wanke, established in 1984, is now the biggest real estate development enterprise in China. Wanke published its equity incentive scheme in March, 2006. And the mode is restricted shares. Wanke was the first listed company in A-stock market to try equity incentive since China implementedListed Company Equity Incentive Management Approach (Implementing).

During its implementation of equity incentive:

1. The first stage of restricted shares implementation scheme was made up of three independent annual plans from 2006 to 2008, one year one plan with each plan falls due in two years and exceeds no more than three years.

2. According to the scheme, under the pre-conditions that return on equity (ROE) exceeds $12 \%$, Wanke withdraws incentive funds from the incremental part of PAT (profit after tax) which is required to increase at a minimum rate of $15 \%$ each year, and the funds can be turned to incentive objects in the third year. After incentive objects have the shares, they can sell at most $25 \%$ of the shares a year.

Analysis of the incentive effects of Wanke's restricted shares:

(1) It improves Wanke's operating level and its performance, enhancing investors' confidence in Wanke. Wanke's earnings per share (EPS), sales growth, ROE are all higher than the industry 
average. Since Wanke implemented restricted shares in 21, March, 2006, the operating and performance level has improved steadily, leading the whole real estate industry.

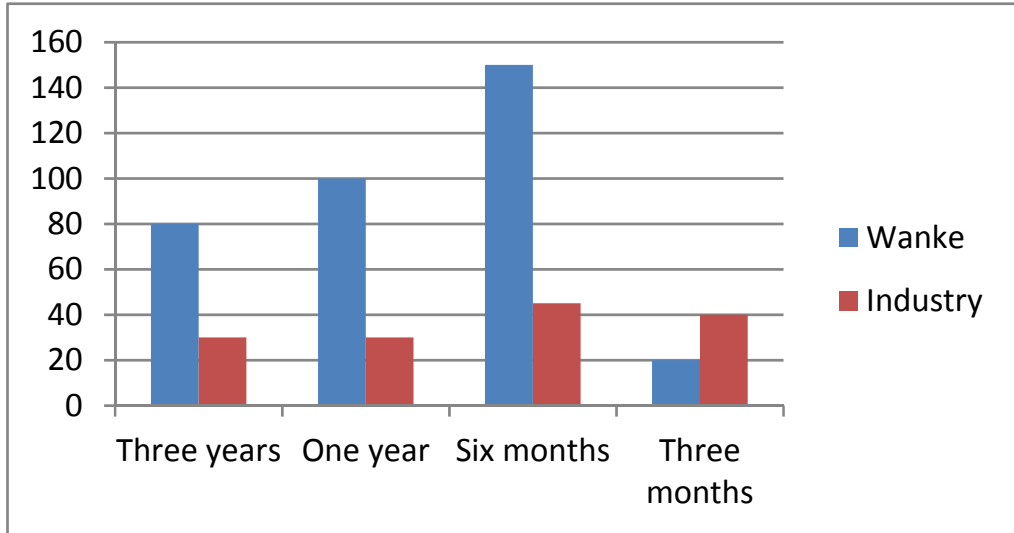

Figure 2: EPS growth

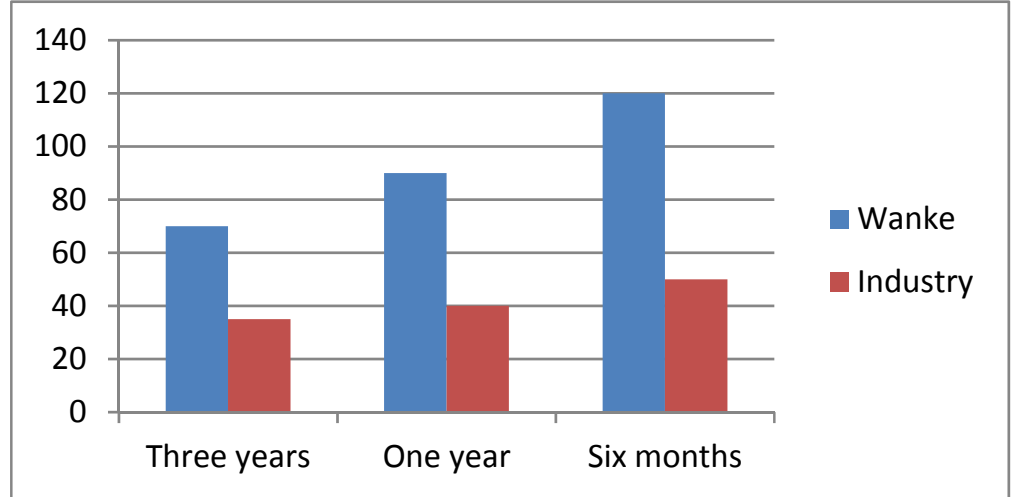

Figure 3: Revenue growth

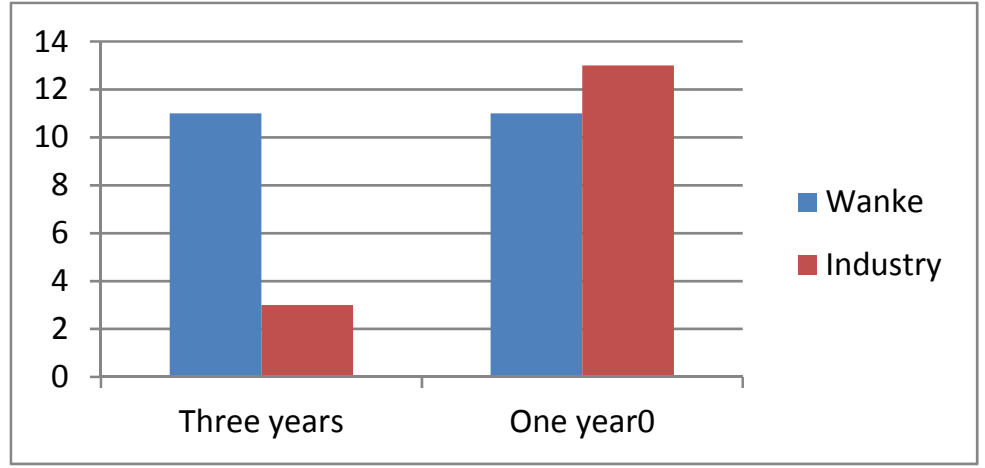

Figure 4: ROE

(2) It improves Wanke's corporate governance. During Wanke's implementation process of restricted shares, each department played its role and strengthened its functions, thus improving Wanke's corporate governance.

(3) It promotes the establishment of shareholders' and managers' benefit-sharing and restriction mechanism. It creates the maximized value for shareholders while assuring managers to pursue 
their own benefits.

(4) It stabilized Wanke's management team. The implementation of restricted shares attracts and stabilizes the talents team, keeping the core talents and improving the core competitiveness as well as the sustainable development of the enterprise.

Summary: It can be concluded that equity incentive can improve the corporate performance through the transmission mechanism of equity incentive to the corporate performance and the case study of Wanke, which is consistent with Hypothesis 1. Implementing equity incentive can improve operators' and employees' working enthusiasm, making them work hard for the future of the enterprise. In this way, the corporate performance will be improved in a certain level, and the managers will also have their own benefits.

\section{Analysis of the relationship between the proportion of equity incentive and the corporate performance}

\subsection{Research design}

\subsubsection{Selection of samples}

In this article, 90 listed companies that implemented equity incentive in 2010 were selected as samples for analysis.

\subsubsection{Selection and analysis of variables}

1. Selection and analysis of explained variables

Explained variables (dependent variables) represent the performance of listed companies, are displayed in ROE.

ROE is the ratio of the PAT and the average net assets of the company in a certain accounting period, representing the profitability and the return on capital of a company, being the key indicator of the Do Pont Analysis Method.

Table 1: Statistical table of ROE

\begin{tabular}{|c|c|c|c|c|c|c|}
\hline ROE & $\geqq 0.3$ & $0.2 \sim 0.3$ & $0.1 \sim 0.2$ & $0.05 \sim 0.1$ & $0.01 \sim 0.05$ & $\leqq 0.01$ \\
\hline No. of enterprises & 2 & 10 & 38 & 34 & 6 & 0 \\
\hline
\end{tabular}

From Table 1 it can be seen that in 2010 ROEs in listed companies which implemented equity incentive followed normal distribution, mostly centering between 0.05-0.2.

2. Selection and analysis of explanatory variables

Explanatory variables (independent variables) represent the level of equity incentive, using HSR (the 
proportion of equity shares in the whole shares of the company) to display. Normally, the bigger HSR is, the higher the level of equity incentive.

Table 2: Analysis of HSR

\begin{tabular}{|c|c|c|c|c|c|c|c|}
\hline Proportion range & $\geqq 6 \%$ & $5 \% \sim 6 \%$ & $4 \% \sim 5 \%$ & $3 \% \sim 4 \%$ & $2 \% \sim 3 \%$ & $1 \% \sim 2 \%$ & $\leqq 1 \%$ \\
\hline No. of enterprises & 5 & 10 & 11 & 14 & 19 & 20 & 11 \\
\hline
\end{tabular}

From Table 2 it can be seen that HSR is well-distributed. Due to the different situations and different implementation of equity incentive scheme of each company and the instability of the capital market, HSR is different in each company.

3. Selection of control variables

Size of company: Modern enterprises' competitiveness is largely dependent on the size. As large-sized enterprises have rich funds, they can invest more capital in products' R\&D as well as the innovation of service, thus they can seize the market opportunities well and make more profits. In addition, large-sized enterprises have better anti-risk capability that they can operate prudently and have better corporate performance. Here we choose the natural logarithm of total assets to represent the size of the enterprise as the control variable.

Growth of company: The growth of the enterprise represents the operating situation as well as the future development potential of the entity, which has great impact on the profitability of the enterprise. If a company earns a high growth and has a prosperous future, it needs the implementation of equity incentive to motivate senior managers, improve their working enthusiasm and optimize their management, benefiting the improvement of the corporate performance. Here we choose the growth rate of net profits to represent the growth of the enterprise.

DR of company: Here we choose D/T ratio (Debt to Total ratio) to represent the debt ratio. D/T ratio is the ratio of the total debts to the total assets of the company, reflecting the debt structure.

The shareholding ratio of the largest shareholder (Z): The bigger the shareholding ratio of the largest shareholder is, the more centralized the shares are. In this case, there's less possibility that equity incentive can be implemented as other shareholders are less likely to compete with him, so the effect of implementing equity incentive is not good.

Table 3: Variables list

\begin{tabular}{|c|c|}
\hline Corporate performance(ROE) & Return on equity \\
\hline Ratio of equity incentive (HSR) & Proportion of incentive shares in total \\
\hline Size of company (SIZE) & Natural logarithm of total assets \\
\hline Growth of company (GROW) & Drowth rate of net profits \\
\hline Debt ratio of company (DR) & Shareholding ratio of the largest shareholder \\
\hline Shareholding ratio of the largest shareholder (Z)
\end{tabular}




\subsubsection{Establishment of the model}

Set a multivariable liner regression equation:

$\mathrm{ROE}=\mathrm{a}+\beta 1 \mathrm{HSR}+\beta 2 \mathrm{SIZE}+\beta 3 \mathrm{DR}+\beta 4 \mathrm{GROW}+\beta 5 \mathrm{Z}+\S$

\subsection{Analysis of the relations between the proportion of equity incentive and the corporate performance}

\subsubsection{Correlation analysis}

Input the sample's data into SPSS, here's the result after correlation analysis:

Table 4: Correlation

\begin{tabular}{|c|c|c|c|c|c|c|}
\hline & $\begin{array}{l}\text { Proportion } \\
\text { of incentive } \\
\text { shares in } \\
\text { total shares }\end{array}$ & ROE & $\begin{array}{l}\text { Total assets } \\
\text { (size of } \\
\text { company) }\end{array}$ & $\begin{array}{l}\mathrm{D} / \mathrm{T} \\
\text { ratio }\end{array}$ & $\begin{array}{l}\text { Growth } \\
\text { rate of } \\
\text { PAT }\end{array}$ & $\begin{array}{l}\text { Shareholding } \\
\text { ratio of the } \\
\text { largest } \\
\text { shareholder }\end{array}$ \\
\hline $\begin{array}{l}\text { Proportion of } \\
\text { incentive } \\
\text { shares in total } \\
\text { shares } \\
\text { Pearson } \\
\text { correlation } \\
\text { significance } \\
\text { (two sides) } N\end{array}$ & 88 & $\begin{array}{r}-1.03 \\
.341 \\
88\end{array}$ & $\begin{array}{r}-.138 \\
.199 \\
88\end{array}$ & $\begin{array}{r}.030 \\
.782 \\
88\end{array}$ & $\begin{array}{r}.155 \\
.1 \\
50 \\
\\
88\end{array}$ & $\begin{array}{r}-.203 \\
.058 \\
88\end{array}$ \\
\hline $\begin{array}{l}\text { ROE } \\
\text { Pearson } \\
\text { correlation } \\
\text { significance } \\
\text { (two sides) } N\end{array}$ & $\begin{array}{r}-1.03 \\
.341 \\
\\
\\
88\end{array}$ & 1 & $\begin{array}{r}.007 \\
.476 \\
88\end{array}$ & $\begin{array}{r}.285 * \\
* \\
.007 \\
88 \\
\end{array}$ & $\begin{array}{r}.351^{* *} \\
.001 \\
\\
88\end{array}$ & $\begin{array}{r}.123 \\
.254 \\
88\end{array}$ \\
\hline $\begin{array}{l}\text { Total assets } \\
\text { (size of } \\
\text { company) } \\
\text { Pearson } \\
\text { correlation } \\
\text { significance } \\
\text { (two sides) } N\end{array}$ & $\begin{array}{r}-1.38 \\
.199 \\
\\
\\
88\end{array}$ & $\begin{array}{r}.077 \\
.476 \\
88\end{array}$ & $\begin{array}{r}1 \\
\\
88\end{array}$ & $\begin{array}{r}.389 * \\
* \\
.000 \\
88\end{array}$ & $\begin{array}{r}.036 \\
.7 \\
42 \\
\\
88\end{array}$ & $\begin{array}{r}-.127 \\
.237 \\
88\end{array}$ \\
\hline $\begin{array}{l}\mathrm{D} / \mathrm{T} \text { ratio } \\
\text { Pearson } \\
\text { correlation } \\
\text { significance }\end{array}$ & $\begin{array}{l}.030 \\
.782 \\
\end{array}$ & $\begin{array}{r}.285^{* *} \\
.007 \\
88\end{array}$ & $\begin{array}{r}.389 * * \\
.000 \\
88\end{array}$ & 1 & $\begin{array}{r}.085 \\
.433 \\
88\end{array}$ & $\begin{array}{r}.040 \\
.709 \\
88\end{array}$ \\
\hline
\end{tabular}


Table 4, cont.

\begin{tabular}{|c|c|c|c|c|c|c|}
\hline (two sides) $N$ & 88 & & & 88 & & \\
\hline $\begin{array}{l}\text { Growth rate of } \\
\text { PAT } \\
\text { Pearson } \\
\text { correlation } \\
\text { significance } \\
\text { (two sides) } N\end{array}$ & $\begin{array}{r}.155 \\
.150 \\
88\end{array}$ & $\begin{array}{r}.351^{* *} \\
.001 \\
88\end{array}$ & $\begin{array}{r}.036 \\
.742 \\
88\end{array}$ & $\begin{array}{r}.085 \\
.433 \\
88\end{array}$ & $\begin{array}{r}1 \\
\\
88 \\
\end{array}$ & $\begin{array}{r}-.007 \\
.948 \\
88\end{array}$ \\
\hline $\begin{array}{l}\text { Shareholding } \\
\text { ratio of the } \\
\text { largest } \\
\text { shareholder } \\
\text { Pearson } \\
\text { correlation } \\
\text { significance } \\
\text { (two sides) } N\end{array}$ & $\begin{array}{r}-.203 \\
.058 \\
\quad 88\end{array}$ & $\begin{array}{r}.123 \\
.251 \\
88\end{array}$ & $\begin{array}{r}-.127 \\
.237 \\
88\end{array}$ & $\begin{array}{r}.040 \\
.709 \\
88\end{array}$ & $\begin{array}{r}-.007 \\
.948 \\
88\end{array}$ & 1 \\
\hline
\end{tabular}

Note: If bilateral significance is less than 0.01 , then the two variables are significantly correlated in the level of 0.01 ; if bilateral significance is less than 0.05 , thenthe two variables are significantly correlated in the level of 0.05 ;if bilateral significance is less than 0.10 , then the two variables are significantly correlated in the level of 0.10 .

It can be concluded from the data in the table:

(1) The Pearson correlation coefficient of ROE and HSR is -0.103 , or $|r|=0.103$, representing the two variables are negatively correlated, but not significantly correlated. This shows that the scale of equity incentive does not have a great impact on corporate performance.

(2) The Pearson correlation coefficient of ROE and SIZE is 0.077, or $|r|=0.077$, representing the two variables are in slight positive correlation, showing that the size of total assets has little effect on corporate performance.

(3) The Pearson correlation coefficient of ROE and DR is 0.285 , or $|r|=0.285$, with its significance being 0.007 less than 0.01 , showing that these two variables are significantly correlated in the level of 0.01 .

(4) The Pearson correlation coefficient of ROE and GROW is 0.351 , or $|r|=0.351$, with its significance being 0.001 less than 0.01 , showing that these two variables are significantly correlated in the level of 0.01 . The size of PAT has a great impact on the level of ROE.

\subsubsection{Analysis of linear regression equation}

To use the multi-variable linear regression model to explain the relation between equity incentive and corporate performance of listed companies by using ROE as dependent variables, and the proportion 
of incentive shares in total shares as independent variables, using total assets (SIZE), growth rate of net profits (GROW), D/T ratio, shareholding ratio of the largest shareholder as control variables, a multi-variable regression model is set. Here we use SPSS (astatistical software) to undertake linear regression analysis. Here are the results:

(1) Correlation analysis table

Table 5: Correlation

\begin{tabular}{|c|c|c|c|c|c|c|}
\hline & ROE & $\begin{array}{ll}\text { Proportion } & \text { of } \\
\text { incentive shares in } \\
\text { total shares }\end{array}$ & $\begin{array}{l}\text { Total assets } \\
\text { (size of } \\
\text { company) }\end{array}$ & $\begin{array}{l}\mathrm{D} / \mathrm{T} \\
\text { ratio }\end{array}$ & $\begin{array}{l}\text { Growth } \\
\text { rate of } \\
\text { PAT }\end{array}$ & $\begin{array}{l}\text { Shareholding } \\
\text { ratio of the } \\
\text { largest } \\
\text { shareholder }\end{array}$ \\
\hline $\begin{array}{l}\text { Pearson } \\
\text { correlation }\end{array}$ & & & & & & \\
\hline ROE & 1.000 & -.104 & .077 & .280 & .351 & .121 \\
\hline $\begin{array}{l}\text { Proportion of } \\
\text { incentive } \\
\text { shares in total } \\
\text { shares }\end{array}$ & $\begin{array}{r}-.104 \\
.077\end{array}$ & -.135 & -.135 & .045 & .155 & $\begin{array}{l}-.206 \\
-.116\end{array}$ \\
\hline Total assets & & & & & & \\
\hline (size of & .280 & .045 & .389 & 1.000 & .087 & .049 \\
\hline company) & .351 & .155 & .036 & .087 & 1.000 & .004 \\
\hline $\begin{array}{l}\mathrm{D} / \mathrm{T} \text { ratio } \\
\text { Growth rate of } \\
\text { PAT } \\
\text { Shareholding } \\
\text { ratio of the } \\
\text { largest } \\
\text { shareholder }\end{array}$ & .121 & -.206 & -.116 & .049 & .004 & 1.000 \\
\hline Sig (one side) & & & & & & \\
\hline ROE & . & .167 & .237 & .004 & .000 & .129 \\
\hline $\begin{array}{l}\text { Proportion of } \\
\text { incentive } \\
\text { shares in total } \\
\text { shares }\end{array}$ & .167 & .104 & .104 & $\begin{array}{l}.339 \\
.000\end{array}$ & .073 & $\begin{array}{l}.026 \\
.139\end{array}$ \\
\hline Total assets & & & & & & \\
\hline (size of & .004 & .339 & .000 & & .209 & .325 \\
\hline company) & .000 & .073 & .369 & .209 & & .483 \\
\hline $\begin{array}{l}\mathrm{D} / \mathrm{T} \text { ratio } \\
\text { Growth rate of } \\
\text { PAT } \\
\text { Shareholding } \\
\end{array}$ & .129 & .026 & .139 & .325 & .483 & \\
\hline
\end{tabular}


Table 5, cont.

\begin{tabular}{|c|c|c|c|c|c|c|}
\hline \multicolumn{7}{|l|}{$\begin{array}{l}\text { ratio of the } \\
\text { largest } \\
\text { shareholder }\end{array}$} \\
\hline$N$ & 89 & & & & & \\
\hline ROE & 89 & 89 & 89 & 89 & 89 & 89 \\
\hline $\begin{array}{l}\text { Proportion of } \\
\text { incentive }\end{array}$ & & 89 & 89 & 89 & 89 & 89 \\
\hline $\begin{array}{l}\text { shares in total } \\
\text { shares }\end{array}$ & 89 & 89 & 89 & 89 & 89 & 89 \\
\hline Total assets & 89 & 89 & & & & \\
\hline (size of & 89 & 89 & 89 & 89 & 89 & 89 \\
\hline company) & 89 & 89 & 89 & 89 & 89 & 89 \\
\hline $\mathrm{D} / \mathrm{T}$ ratio & & & 89 & 89 & 89 & 89 \\
\hline Growth rate of & & & & & & \\
\hline PAT & & & & & & \\
\hline Shareholding & & & & & & \\
\hline ratio of the & & & & & & \\
\hline largest & & & & & & \\
\hline shareholder & & & & & & \\
\hline
\end{tabular}

(2) Model summary table

Table 6: Model Summary ${ }^{\mathrm{b}}$

\begin{tabular}{|c|c|c|c|c|c|c|c|c|c|}
\hline Model & $\mathrm{R}$ & $\mathrm{R}^{2}$ & Adjusted & Standard estimate's & \multicolumn{4}{|c|}{ Change statistics } \\
\cline { 5 - 9 } & & & $\mathrm{R}^{2}$ & error & $\begin{array}{c}\text { Change } \\
\mathrm{R}^{2}\end{array}$ & $\begin{array}{c}\text { Change } \\
\mathrm{F}\end{array}$ & $\mathrm{df1}$ & $\mathrm{df2}$ & $\begin{array}{c}\text { Change } \\
\text { Sig.F }\end{array}$ \\
\hline 1 & $.472^{\mathrm{a}}$ & .223 & .176 & .0749337 & .223 & 4.756 & 5 & 83 & .001 \\
\hline
\end{tabular}

a. Predictive variables (constants): Proportion of incentive shares in total shares, Total assets (size of company), D/T ratio, Growth rate of PAT, Shareholding ratio of the largest shareholder

b. Dependent variable: ROE

(3) Table of the F test values of the model

Table 7: Anova $^{\mathrm{a}}$

\begin{tabular}{|r|r|r|r|r|r|}
\hline Model & Quadratic sum & df & Mean square & F & Sig. \\
\hline regression & .134 & 5 & .027 & 4.756 & $.001^{\mathrm{b}}$ \\
residual & .466 & 83 & .006 & & \\
sum & .600 & 88 & & & \\
\hline
\end{tabular}

a. Dependent variable: ROE

b. Predictive variables (constants): Proportion of incentive shares in total shares, Total assets (size of company), D/T ratio, Growth rate of PAT, Shareholding ratio of the largest shareholder 
(4) Table of correlation analysis of the model

Table 8: Coefficient ${ }^{\mathrm{a}}$

\begin{tabular}{|c|c|c|c|c|c|c|c|c|c|}
\hline \multirow[t]{2}{*}{ Model } & \multicolumn{2}{|c|}{$\begin{array}{l}\text { Non standardized } \\
\text { coefficient }\end{array}$} & \multirow{2}{*}{$\begin{array}{l}\text { Standardized } \\
\text { coefficient }\end{array}$} & \multirow[t]{2}{*}{$\mathrm{t}$} & \multirow[t]{2}{*}{ Sig } & \multicolumn{2}{|c|}{$\begin{array}{c}\text { B’s 95\% } \\
\text { confidence } \\
\text { interval }\end{array}$} & \multicolumn{2}{|c|}{ Co-linear statistics } \\
\hline & B & $\begin{array}{c}\text { Stand } \\
\text { ardize } \\
d \text { erro } \\
r\end{array}$ & & & & $\begin{array}{l}\text { Lowe } \\
\text { r limi } \\
t\end{array}$ & $\begin{array}{l}\text { Uppe } \\
\text { r lim } \\
\text { it }\end{array}$ & Allowance & VIF \\
\hline 1 (Constants) & .086 & .028 & & 3.042 & .003 & .030 & .142 & & \\
\hline $\begin{array}{c}\text { Proportion of } \\
\text { incentive shares }\end{array}$ & -.008 & .005 & -.165 & $\begin{array}{c}-1.61 \\
3\end{array}$ & .110 & -.017 & .002 & .892 & 1.121 \\
\hline in total shares & $-2.841 \mathrm{E}$ & .000 & -.058 & & .595 & .000 & .000 & .796 & 1.257 \\
\hline $\begin{array}{l}\text { Total assets (size } \\
\text { of company) }\end{array}$ & -013 & .039 & .276 & -.534 & .011 & . 023 & .177 & .822 & 1.216 \\
\hline $\mathrm{D} / \mathrm{T}$ ratio & .100 & .009 & .355 & 2.588 & .001 & .014 & .049 & .967 & 1.034 \\
\hline $\begin{array}{l}\text { Growth rate of } \\
\text { PAT } \\
\text { Shareholding } \\
\text { ratio of the } \\
\text { largest } \\
\text { shareholder }\end{array}$ & $\begin{array}{l}.031 \\
.036\end{array}$ & .055 & .065 & $\begin{array}{c}3.605 \\
.648\end{array}$ & .519 & -.074 & .145 & .919 & 1.088 \\
\hline
\end{tabular}

a. Dependent variable: $\mathrm{ROE}$

It can be seen from the regression analysis results that $\mathrm{R}$ — coefficient of determination of the model is $0.472, R^{2}$ equals to 0.223 , showing that the model has a good fitting precision. The F-statistics is 4.756 and sig.F_— the concomitant probability is 0.001 , showing that the model is significant in a whole. All VIFs are less than 10, showing the regression model does not have multicollinearity problems and the results are convincible.

The regression model of corporate performance and the percentage of equity incentive is:

$R O E=0.086-0.165 H S R-0.058$ SIZE $+0.276 D R+0.355$ GROW $+0.065 Z+\S$

Summary of this section: It can be concluded form the results from the correlation analysis and the regression analysis that the equity incentive percentage in 2010 is weakly negatively correlated to corporate performance with an insignificant correlation, which is against the hypothesis 2 . This shows that with a higher percentage of equity incentive, it can't be ensured that the corporate performance will be better. Factors like the appropriateness of implementing equity incentive, whether the scheme is implemented in place, the environment of capital market will affect the effects of the implementation of equity incentive, thus influencing the corporate performance. 


\section{Analysis of the effects of equity incentive modes.}

\subsection{Comparative analysis of two common incentive modes}

Basic modes of equity incentive include share options, restricted shares, SARs, performance shares, phantom shares and so on, with different incentive effects by different incentive modes. According to the analysis of Annual Report of Equity Incentive of Listed Companies (2010)by Shanghai Jingbang Group, in 2010, 73\% of listed companies chose share option mode, $26 \%$ of them chose restricted shares mode while $1 \%$ chose SARs mode. It can be seen from the schemes of listed companies which have implemented equity incentive so far that most of them chose only share option mode or only restricted shares mode. So, in this section, these two modes will be compared and analyzed.

Table 9: Table of comparisons between share option and restricted shares

\begin{tabular}{|c|c|c|}
\hline Differences & Share option & Restricted shares \\
\hline $\begin{array}{l}\text { Different symmetries of rights } \\
\text { and obligations }\end{array}$ & $\begin{array}{l}\text { (1) Asymmetrical rights and } \\
\text { obligations. } \\
\text { (2) Incentive objects have exercise } \\
\text { rights without taking responsibility } \\
\text { for exercising rights. The rights can } \\
\text { be exercised or waived. }\end{array}$ & $\begin{array}{l}\text { (1) Symmetrical rights and } \\
\text { obligations } \\
\text { (2) Incentive objects can gain } \\
\text { shares after meeting grant } \\
\text { conditions. Shares must be kept } \\
\text { within the restrict period, and they } \\
\text { can't be sold or transferred. }\end{array}$ \\
\hline $\begin{array}{l}\text { Different symmetries of incentive } \\
\text { and punishment }\end{array}$ & $\begin{array}{l}\text { (1) Only has incentive effects but } \\
\text { not punitive effects. } \\
\text { (2) Holders can choose to exercise } \\
\text { rights to obtain gains when share } \\
\text { price rises while they can waive the } \\
\text { rights to avoid losses when share } \\
\text { price falls. }\end{array}$ & $\begin{array}{l}\text { (1) Might have punishments } \\
\text { (2) Incentive gains rise with share } \\
\text { price rising and falls with share } \\
\text { price falling. When share price } \\
\text { falls under the purchase price, } \\
\text { holders will face capital loss. }\end{array}$ \\
\hline $\begin{array}{c}\text { Different regulations about } \\
\text { waiting period, lock-up period } \\
\text { and unlock period }\end{array}$ & $\begin{array}{l}\text { (1) After holders have been granted } \\
\text { share options for a year of waiting } \\
\text { period, it comes to exercise period. } \\
\text { (2) After purchasing shares, there } \\
\text { won't be limits about the selling and } \\
\text { transfer of the shares. }\end{array}$ & $\begin{array}{l}\text { (1) When indicators such as PAT, } \\
\text { EPS of the company reach the } \\
\text { standard, incentive objects can } \\
\text { gain a certain amount of shares. } \\
\text { (2) After being granted, holders } \\
\text { have to wait for unlock period } \\
\text { until the lock-up period passes. } \\
\text { And they won't gain the } \\
\text { circulation rights of the shares } \\
\text { until unlocking conditions have } \\
\text { been met. }\end{array}$ \\
\hline
\end{tabular}


Table 9, cont.

\begin{tabular}{|c|c|c|}
\hline $\begin{array}{c}\text { Different exercise price and grant } \\
\text { price }\end{array}$ & $\begin{array}{l}\text { The exercise price is higher or equal } \\
\text { to the market price when the } \\
\text { incentive scheme was published. }\end{array}$ & $\begin{array}{l}\text { The grant price is usually lower } \\
\text { that the market price when the } \\
\text { incentive scheme was published. }\end{array}$ \\
\hline Different incentive numbers & $\begin{array}{l}\text { The number of shares is usually } \\
\text { determined before issuing, and it } \\
\text { won't exceed } 10 \% \text { of total share } \\
\text { capital. }\end{array}$ & $\begin{array}{l}\text { The number of shares can be } \\
\text { determined before or after issuing. } \\
\text { (1) Pre-determination : The } \\
\text { company extracts incentive funds } \\
\text { according to the annual } \\
\text { performance, which is used to } \\
\text { purchase underlying shares. } \\
\text { (2) Post-determination: The } \\
\text { number of shares is determined by } \\
\text { the amount of incentive funds and } \\
\text { the complete status of annual } \\
\text { profit. }\end{array}$ \\
\hline Different ways of taxation & $\begin{array}{l}\text { Taxation not needed when granted. } \\
\text { When holders decide to exercise } \\
\text { rights to purchase shares, the } \\
\text { difference between which that the } \\
\text { exercise price is lower than the } \\
\text { market closing price of that day will } \\
\text { be the tax base, and income tax will } \\
\text { be charged according to salaries' tax } \\
\text { criteria. After exercising rights, } \\
\text { income tax won't be charged when } \\
\text { shares are transferred. }\end{array}$ & $\begin{array}{l}\text { When incentive objects confirm to } \\
\text { purchase restricted shares, they } \\
\text { will be charged income tax } \\
\text { according to regulations. Income } \\
\text { tax won't be charged when } \\
\text { restricted shares are transferred. }\end{array}$ \\
\hline
\end{tabular}

To conclude, it's better equity incentive schemes to comprise both rights and obligations, and to have both incentive and punitive effects, thus having a better incentive effects.

\subsection{Descriptive analysis.}

57 listed companies are chosen from 90 ones which implemented equity incentive in 2010. There are 42 (73\%) of them implementing share option schemes while 15 (26\%) of them implementing restricted shares schemes. Here is a descriptive analysis of PAT, EPS, ROE of these companies in 2009 and 2010. 
Table 10: Statistical list of related data of the two modes

\begin{tabular}{|c|c|c|c|c|c|c|c|}
\hline \multirow{2}{*}{ Incentive modes } & \multirow{2}{*}{$\begin{array}{c}\text { Sample } \\
\text { size }\end{array}$} & \multicolumn{2}{|c|}{ Average PAT (0000’) } & \multicolumn{2}{c|}{ Average EPS } & \multicolumn{2}{c|}{ Average ROE } \\
\cline { 3 - 8 } & 2009 & 2010 & 2009 & 2010 & 2009 & 2010 \\
\hline Share option & 42 & 61670 & 81248 & 0.4499 & 0.5225 & $11.94 \%$ & $15.68 \%$ \\
\hline $\begin{array}{c}\text { Restricted } \\
\text { shares }\end{array}$ & 15 & 14072 & 17222 & 0.5473 & 0.5595 & $10.47 \%$ & $11.75 \%$ \\
\hline
\end{tabular}

It can be seen from the data of Table 10 that:

(1) Vertical analysis: Average PAT, EPS, ROE in 2010 are all higher than that of 2009, whatever the mode.

Share option: Average PAT increases 32\% from 2009 to 2010, average EPS increases 16\% from 2009 to 2010, and average ROE increases 31\% from 2009 to 2010.

Restricted shares: Average PAT increases 22\% from 2009 to 2010, average EPS increases 2\% from 2009 to 2010, and average ROE increases 12\% from 2009 to 2010.

Conclusion 1: The effect of implementation is good as a whole whatever the mode. As the increase in average PAT, EPS, ROE of share option is greater than that of restricted shares, so the implementing effects of share option are better.

(2) Horizontal analysis: The average PAT and ROE of implementing share option are better than that of restricted shares in both 2009 and 2010. However in these two modes, the difference between average ROE is not big. The average EPS of implementing restricted shares is better than that of share option in both 2009 and 2010, with a small difference.

Conclusion 2: Effects of implementing share option are better in the view of statistics, but these two modes have a small difference between the implementing effects.

Summary of this section: It is against hypothesis 3 that different modes of equity incentive have different effects but the difference is not significant. The way an enterprise chooses the incentive mode is affected by the stage it's in, its nature, its size and many other factors. An enterprise can only choose effective equity incentive schemes (better with both incentive and constraint effects) by relating to its conditions as well as taking the environment of capital market into consideration. Whether implementing equity incentive can be successive or not depends on many factors.

\section{Conclusions}

The corporate performance can only be improved and the personal gain can only be achieved byimplementing effective equity incentive schemes according to the corporate specific circumstances with the research of the relations between equity incentive in listed companies and the corporate performance, to motivate senior managers and employees in the company to work actively and make decisions in the company's view of interest, to bind the personal interest with that of the company. 
(1) Appropriate equity incentive can increase the work activism of employees and improve the corporate performance. So implementing equity incentive can help improve corporate performance in a certain level.

(2) By the correlation analysis and the regression analysis of data of 90 listed companies that implemented equity incentive in 2010 collected by SPSS software, the results present a weak negative correlation, which means the percentage of equity incentive does not have a significant influence on the corporate performance. However, increase in PAT presents a significant positive correlation with that of ROE, and the increase in PAT has a great influence in ROE.

(3) There are many types of equity incentive modes that different enterprises focus on different things when implementing them, with different incentive effects. The difference in effects of share option mode and that of restricted shares is not significant. Equity incentive schemes with both incentive and constraint effects will have better motivating effects.

\section{Acknowledgement}

The research is supported by National Natural Science Foundation of China (71101076), MOE Layout Foundation of Humanities and Social Sciences (10YJA630147), and Natural Science Foundation of Nantong University(10ZY002)

\section{References}

Fama, E. , Jensen M.C.Separation of Ownership And Control.Journal of Law And Economics.1983(26):301-326.

Jensen, M. C. and Murphy, K. J., Performance Pay And Top Management Incentive.Journal of Political Economy.1982:321-328.

Jensen, M. C. and Meckling, Theory of The Firm:Managerial Behavior, Agency Costs And Ownership Structure, Journal of Financial Economics.1976(3):305-360.

Morck, R., Shleifer, A. and ishny, R. W., Management Ownership And Market Valuation, Empirical Analysis Journal of Financial Economics.998(20):293-315.

Demsetz, H. and Lehn, K., The Structure of Corporate Ownership:Causes And Consequences.Journal of Political Economy.1985(93):155-177.

Demsetz, H. The Structure of Ownership And theory of Firm, Journal of Low And Economics.1983(26):375-393. 